\title{
Mock-up Process Analysis for Development of Prefabricated Korean Style House (Han-ok)
}

\author{
Lee, Chang-Jae ${ }^{1, a}$ Lim, Seok-ho ${ }^{2, b}$ \\ ${ }^{1}$ Research Fellow, Korea Institute of Civil Engineering and Building Technology, \\ South Korea \\ ${ }^{2}$ Senior Research Fellow, Korea Institute of Civil Engineering and Building Technology, \\ South Korea \\ avolgary@kict.re.kr , 'bshlim@kict.re.kr
}

Keywords: Korean Style House, Unit, Prefabricated, Mock-Up, Modular Architecture, Korean Traditional Architecture, Han-ok.

Abstract. This study has been carried out to prepare basic data for modular Korean style house (Han-ok) which is to be continuously developed in the future. In doing so, errors and problems of de signing, manufacturing and transportation in mock-up process of prefabricated Korean style house $h$ ave been analyzed and supplemented for economic feasibility, construct ability and performance imp rovement.The contents of Mock-up process can be summarized as follows. Firstly, errors occurred b $y$ the bending characteristic of lumber has been found regarding securement interval of existing buff er zone. Therefore the zone needs to be extended by $15 \mathrm{~mm}$. Secondly, efficiency of assembly is set a ccording to slope and smoothness of the land changes during assembly of unit module on the site. Th erefore, pre-consideration according to the current status of the land is required. Thirdly, packaging $\mathrm{m}$ ethod and Box need to be developed for safe transportation irrespective of climate change. About tw o weeks have been required for mock-up process for prefabricated Korean style house. This model $r$ educes construction period that continuous development through modification and supplementation o $\mathrm{f}$ problems appear during designing, manufacturing, transportation and assembly processes would $\mathrm{m}$ ake it possible to develop a new type of Korean style house for improvement of construction period a nd costs of previous Korean style house.

\section{Introduction}

\section{1) Background and Objective}

Korean style house (Han-ok), which has been the traditional residential place of Korea, has changed and evolved according to the period and user demands. Since Korean style house has received attention recently, many studies and development are being carried out for improvement and advancement of such house. Especially, studies and development for introduction of prefabricated assembly system are being performed a lot as a measurement for standardization of performance of the house and cutting the high-price deviating from the previous manual architectural method in the past. The prefabricated assembly method is for building houses though completion of the majority of parts of house in advance for minimization of procedures in site. Such method may result in reduction of construction waste, recycling of materials, quality standardization, reduction of construction period and costs. In this study, mock-up process for prefabricated Korean style house has been developed by application of unit module and specific development technology of joints which have already been developed for procedure for development of prefabricated Korean style house. The purpose has been for prediction of reliability by deduction of improvement measurement through figuring out the problems appear in designing, manufacturing and transportation procedures. Multi-field studies are required for activation of distribution of Korean style house with low price and short construction period. Above all, this study has been conducted to provide basic data for prefabricated Korean style house, which is to be continuously developed in the future, by analyzing designing, transportation and assembly processes of mock-up process of prefabricated Korean style house. 


\section{2) Scope and Method}

This study focuses on mock-up의 production Process for development of Korean style house that the contents deal with designing, producing, assembly, transportation \& lifting, disassembly, storage. In this article, overview of prefabricated Korean style house has been examined firstly. Secondly, procedures of each of mock-up process have been analyzed. In designing part, standard of unit module is set as well as designing drawing and detailed drawing of joint have been developed. Further, mock-up has been divided into unit structure and roof structure according to unit module drawing and detailed drawing of unit module developed for development process then they have been manufactured in factory. In transportation and lifting part, the manufactured unit and roof structures have been lifted and transported then the structure has been assembled in site. In addition, the assembled Korean style house has been disassembled, transported then stored. According to these procedures, the results from each mock-up process have been arranged in conclusion part.

\section{Overview of Prefabricated Korean Style House}

In many other countries in which there are a lot of prefabricated assembly house, various types of constructions are being designed and produced by application of prefabricated assembly procedure for reduction of construction waste, energy saving, reduction of construction period and recycling of construction material. In Korea, such type of house is begin utilized for military camp for soldiers and temporal houses in need of the prefabricated assembly houses.

Traditional Korean style house consists of space system, (間) which refers to size or area according to length between pillars and the number of pillars. Space is constituted according to pillars in care of traditional house. In the same manner, unit structure constitutes the space in case of prefabricated Korean style house. The structure of unit box works as pillar and the structures constitutes a residential space. For this reason, Korean style house, which utilizes prefabricated assembly method, is being utilized as an alternative for new Korean style house.

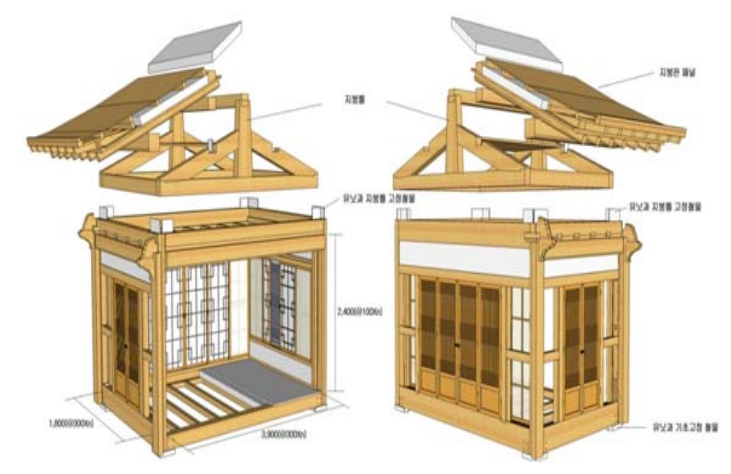

Fig 1. Overview of Prefabricated Korean Style House Mock-up

\section{Construction of Prefabricated Korean Style House Mock-up}

\section{1) Design of Prefabricated Korean Style House}

In this study, Korean style house $\left(43.0 \mathrm{~m}^{2}\right)$ has been designed for mock-up process and the roof is gable type of which height is $5.4 \mathrm{~m}$. The unit which consists of kitchen, living room and toilet has been simplified as one type. Unit has been designed with $2850 \times 3450 \times 2700 \mathrm{~mm}$ of size while inside dimension has been set as $2700 \times 3300 \times 2400 \mathrm{~mm}$ for Modular coordination designing through $300 \mathrm{~mm}$ of increment. 


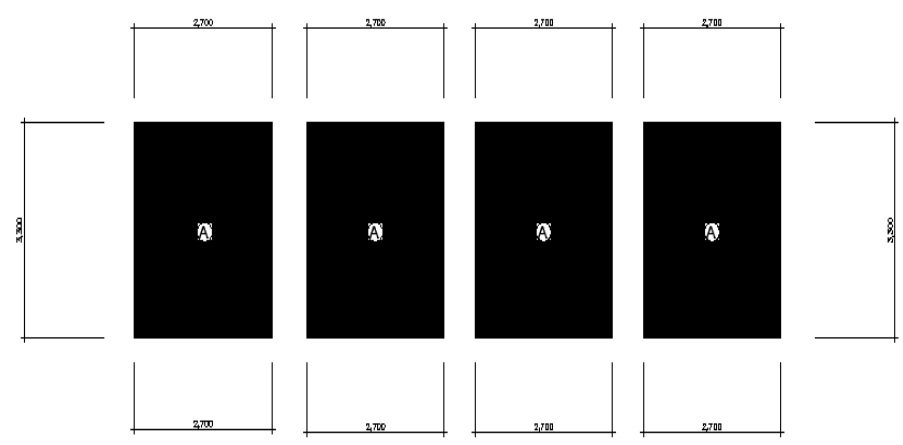

Fig 2. Floor Plan of Mock-Up Arrangement of Prefabricated Korean Style House Mock-up Table 1. Overview of Construction of Prefabricated Korean Style House

\begin{tabular}{|c|c|c|c|}
\hline \multirow{2}{*}{ Classification } & \multicolumn{2}{|c|}{ Contents } & $10.70 \mathrm{~m}^{2}$ \\
\hline \multirow{3}{*}{ Building Area } & & Living Room & $10.70 \mathrm{~m}^{2}$ \\
\cline { 3 - 4 } & \multirow{3}{*}{$42.80 \mathrm{~m}^{2}(13 \mathrm{tr})$} & Main Room & $5.35 \mathrm{~m}^{2}$ \\
\cline { 3 - 4 } & & Bath Room & $3.15 \mathrm{~m}^{2}$ \\
\cline { 3 - 4 } & & Kitchen & $2.20 \mathrm{~m}^{2}$ \\
\cline { 3 - 4 } & & Boiler Room & $10.70 \mathrm{~m}^{2}$ \\
\hline Maximum Height & & Loft & \\
\hline Major Structure & & $5.4 \mathrm{~m}$ & \\
\hline
\end{tabular}

Floor shape is '- ' that it consists of not many rooms therefore double sliding window has been installed for living rooms as major as well. Kitchen has been designed as LD-K type that the users can have meal in living room sitting on the floor. Further, bath room unit has been designed with $5.35 \mathrm{~m}^{2}$ size which is the half size. Kitchen and boiler room have been designed with $3.15 \mathrm{~m}^{2}$ and $2.20 \mathrm{~m}^{2}$ sizes.

Pillar size has been set as $150 \mathrm{~mm}$ while $10 \mathrm{~mm}$ of buffer zone has been secured for joint of units for better construct ability.
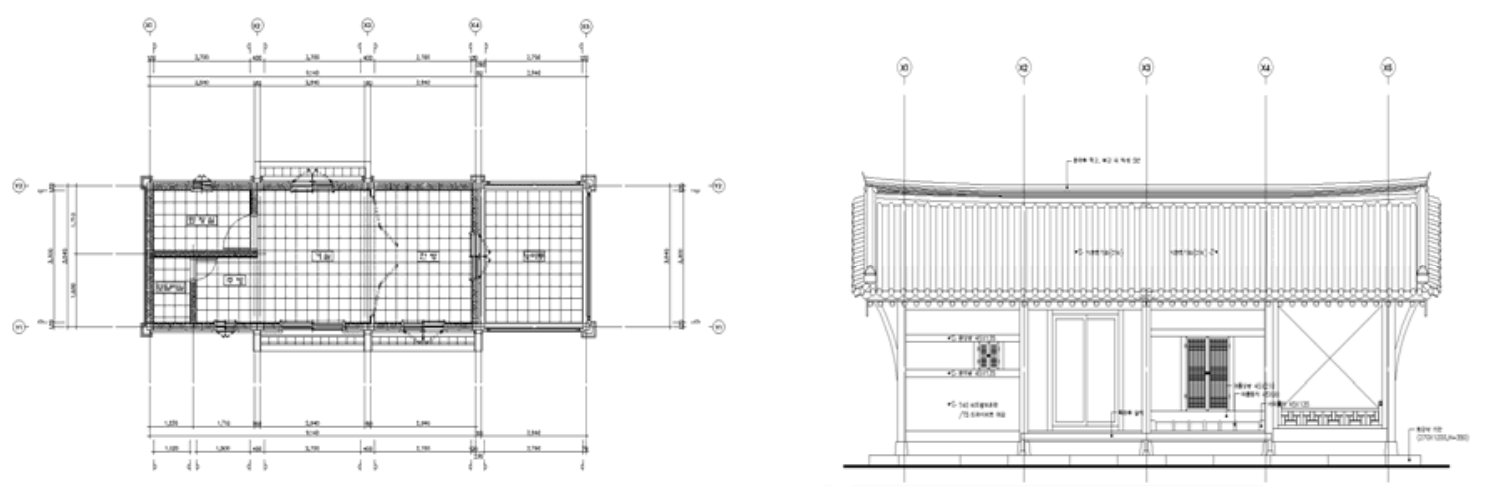

Fig 3. Floor Plan of Prefabricated han-ok

Fig 4. Elevation of Unit Prefabricated han-ok 
buffer zone between units have been secured for construct ability during design process. However, contact between units have not been smooth during assembly. Accordingly, it has not been sufficient for supplementation of bend of materials. Therefore more than $10 \mathrm{~mm}$ of buffer zone interval would be required in the future.

Table 2. Assembly on the Site
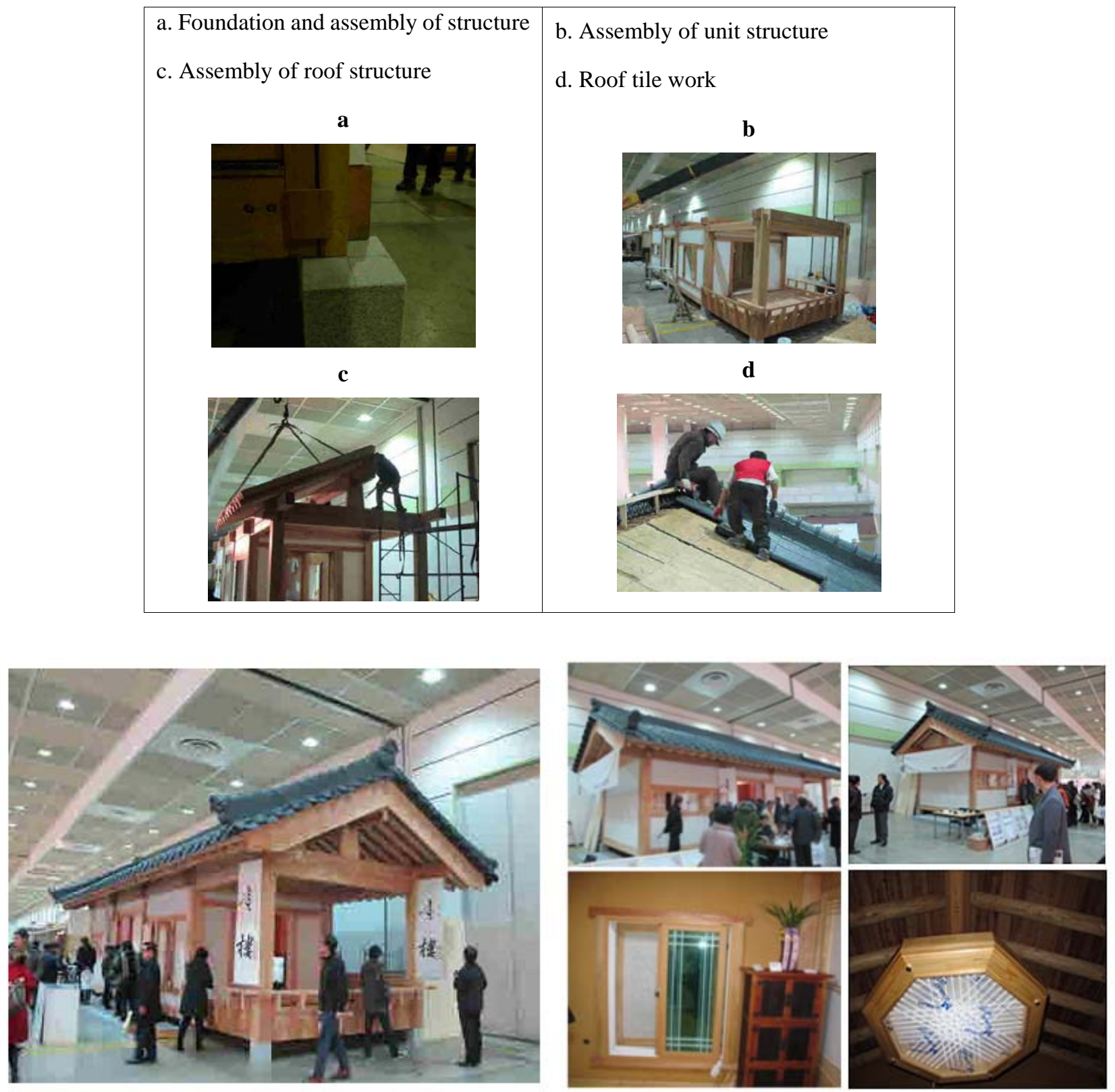

Fig 5. Inside and Outside Prefabricated Korean Style House Mock-up

\section{5) Disassembly and Storage of Unit Prefabricated Korean Style House Mock-up}

Disassembly has been processed in inverse order of assembly. Firstly, roof tile has been disassembl ed followed by roof and unit structures. The disassembled materials have been classified for each ty pe for safe transportation. The disassembled structures have been transported to warehouse for stora ge. In doing so, foundation stone, unit structure and roof structure have been assembled respectively then they have been covered with packaging material in case of rain. 


\section{Conclusion}

The results from each mock-up stage are as follows. Firstly, buffer zone has been set as $10 \mathrm{~mm}$ to secure construction ability for assembly of structures for designing unit module Korean style house. In fact, the results from assembly of mock-up indicate that the error caused by bending of lumber material cannot be supplemented through the previous buffer zone interval. Therefore, buffer zone needs to be extended to be $15 \mathrm{~mm}$. Secondly, for site assembly, imbalanced land level can cause contact between structures leading to increase times required for assembly. This has not been reviewed for designing Prefabricated Korean Style House that efficiency of assembly is determined according to slope and smoothness therefore consideration on land according to such factors need to be followed. Thirdly, for transportation of unit structure, packaging and box need to be developed for prevention of contamination and damage caused by foreign substance. Especially, the packaging and box development for safe transportation irrespective of climate are required.

Average three months have been required for construction of previous Korean style house. However, only two weeks have been required for mock-up process of Prefabricated Korean Style House. Even if we take into account the process has been mock-up one, there would be a lot of reduction in construction period. Therefore, this method would promote opportunities for providing high-quality prefabricated Korean style house at rational price through continuous development by modifying and supplementing problems appear in designing, transportation and assembly procedures.

\section{Acknowledgement}

This study was carried out with financial support from the research project titled " OneDay Housing of Construction Technology Development, 2015"carried out by the Korea Institute of Civil Engineering and Building Technology.

\section{Reference}

[1] Baek, S., \& Lee, Y. (2011). Developing an application for prefabrication panel system based on Building Information Modeling, Proceeding of autumn Annual Conference of Architectureal Institute of Korea, 209-210

[2] Cho, Y., \& Jo, G. (2008). A Study on the Development of an Intelligent Modeler for Modernized Korean Traditional Buildings using BIM Systems, Journal of the Housing Association, 19(6), 55-62

[3] Choi, B., \& Cho, J, (2012), A Basic Study on Hanok Wooden Structure Modeling Process based on BIM, Journal of Architectural Institute of Korea 28(2), 121-130

[4] Choo, S., \& Lee, K., \& Park, S. (2012). A Study on LOD(Level of Development) for Development of Green BIM Guidelines, Journal of Architectural Institute of Korea 28(6), 37-47

[5] Kim, D., \& Hyun, C., \& Kim, Y, \& Ji, S. (2012). Development of Multi-Housing project maintenance model using BIM, Proceeding of spring Annual Conference of Architectural Institute of Korea, 279-280

[6] Lee, G., \& Lim, S. (2011). A Study on Unit Modular Design Method of Urban-type Housing, Journal of the Housing Association, 22(5), 101-110

[7] Lim, S., \& Lee, G, (2011), A Study on the Standardization of UBR(Unit Bath Room) by Utilizing Reference Plane, Journal of Architectural Institute of Korea 27(1), 81-88

[8] Lee, G., \& Lim, S. (2011). A Study on Unit Modular Design Method of Urban-type Housing, Journal of the Housing Association, 22(5), 101-110 